\title{
Vehicle Insurance Financial Mechanism
}

\author{
Larisa Yuzvovich $^{1}$, Elena Knyazeva ${ }^{1}$, Elena Razumovskaya ${ }^{1} \&$ Vadim Katochikov $^{2}$ \\ ${ }^{1}$ The Insurance Department Ural Federal University named after the first President of Russia B. N. Yeltsin, \\ Yekaterinburg, Russia \\ ${ }^{2}$ Branch OOO Rosgosstrakh-Ural Directorate of Sverdlovsk region, Yekaterinburg, Russia \\ Correspondence: Yuzvovich L. Ivanovna, The Insurance Department Ural Federal University named after the \\ first President of Russia B. N. Yeltsin, Yekaterinburg St. World, 19, Yekaterinburg, 620002, Russia.
}

Received: December 20, 2014 Accepted: January 5, 2015 Online Published: February 25, 2015

doi:10.5539/res.v7n3p99 URL: http://dx.doi.org/10.5539/res.v7n3p99

\begin{abstract}
In Russia, over the last decade, vehicle insurance is more and more urgent. This is primarily due to an increase in consumer vehicle market, both new and used. The growth of the vehicle market says about income growth of citizens and their economic well-being. In Russia, over the last decade, vehicle insurance is more and more urgent. This is primarily due to an increase in consumer vehicle market, both new and used. The growth of the vehicle market says about income growth of citizens and their economic well-being. Relevance of vehicle insurance topic is associated with the dynamically developing vehicle market. In a market economy, vehicle insurance is a guarantee of life stability of individual, business entity, and society as a whole. The aim of this work is to develop measures that can increase the profitability of the insurance portfolio of the insurer and to reduce the unprofitableness ratio for vehicle insurance. Today, vehicle insurance share for mandatory and voluntary forms of insurance portfolio in insurance companies is growing. Processes of financial mechanism organised correctly within the company directly affect insurance portfolio profitability. In turn, insurance portfolio profitability consists of the difference between the revenues and expenditures of the company, and profitability on vehicle insurance types depends on the quality and amount of claims settlement, i.e. expenditures side. The result of the "Increased vehicle insurance profitability based on client-oriented approach", which envisages reducing vehicle insurance unprofitableness, will serve as a more transparent rule for insurants of vehicle insurance, wage rates, factors affecting the value of insurance premium. Each client will be able to assess adequately the financial impact because of an insured event.
\end{abstract}

Keywords: financial mechanism of vehicle insurance, insurance reserves, insurance fund, insurance portfolio profitability

\section{Introduction}

Relevance of the topic is related to the rapidly developing vehicle market in the Russian Federation. In a market economy, vehicle insurance is to guarantee the stability of life of a single person, business entity, and society as a whole. Today, the share of $\mathrm{CNC}$ and $\mathrm{OMI}$ vehicle insurance in the insurance portfolio of insurance companies is growing. Processes of financial mechanism organised correctly within the company directly affect insurance portfolio profitability. In turn, insurance portfolio profitability is the sum of the difference between revenues and expenditures of the company. Return on vehicle insurance depends on the quality and quantity of unprofitableness settlement, i.e. expenditure side. In Russia, there is a situation that vehicle insurance comprises high-risk operations. Most insurance companies work with unprofitableness on the main products of vehicle insurance - $\mathrm{CNC}$ and OMI, reaching up to $100 \%$, it leads and is a source of foul play of vehicle insurance entities.

Topical and controversial features of theoretical and methodological foundations of vehicle insurance, high practical importance of insurance services at the vehicle insurance market in the modern economic system determined the purpose and objectives, as well as the choice of the object and the subject of the study.

The aim of this work is to develop measures that can increase insurance portfolio profitability of the insurer and reduce unprofitableness ratio for vehicle insurance.

The stated goal demanded solving specific theoretical, methodological, and practical problems of research: 
1) The study of the constituent elements of the financial mechanism and its work in the insurance companies.

2) Identification of the main features of financial policy in the management expenses of the insurance company.

3) The study of such elements formation as the financial mechanism of insurance rates and insurance coefficients.

4) The study of factors influencing the formation of insurance coefficient value.

The subject of research includes economic relations arising in the process of formation and implementation of the financial mechanism of vehicle insurance. The object of study is SOGAZ, OJSC.

Theoretical and methodological basis of the study comprises of analytical and statistical analysis methods.

The empirical base of research in its theoretical parts are the works of Russian and foreign scientists and experts in the field of insurance and vehicle insurance. The practical part of the research information base is made up by federal laws and normative acts of the Russian Federation and its members on the issues of insurance, vehicle insurance rates, tariffs on the compulsory vehicle insurance, internal documents of SOGAZ, OJSC (regulations, rules, orders, memoranda and applications to them), published in the media and on the Internet.

The theoretical significance of the dissertation research is that the results obtained by the author in the study, complement existing theoretical ideas about the nature of vehicle insurance, economic relations arising in the formation of the financial mechanism of vehicle insurance.

The practical significance of the study is determined by the possibility of the practical use of the results and guidelines developed in order to reduce unprofitableness of basic vehicle insurance types - $\mathrm{CNC}$ and $\mathrm{OMI}-$ and increase insurance portfolio profitability.

Implementation of financial goals and objectives of any insurance company is made through the work of the financial mechanism. The work of the financial mechanism consists of various methods for organization of financial relations both within the enterprise and between subjects of economic relations.

We propose to consider the structure of the financial mechanism for vehicle insurance in the modernization of the insurance relationship (Figure 1).

The financial mechanism elements operating within the insurance company include insurance premiums, which make up the insurance fund. Insurance fund is the main element, the very essence of the insurance company. It is from the insurance fund, insurance payments are made because of the onset of the case provided in the insurance agreement. The fund is formed from the proceeds of premiums insurants. In turn, insurance premium value consists of the net rate and surcharges. Net rate contributes to the formation of the insurance fund from which the insurance premiums and premium rate covers the costs associated with the organization of the company (maintenance of management, office rent, staff costs, management costs, etc.). 


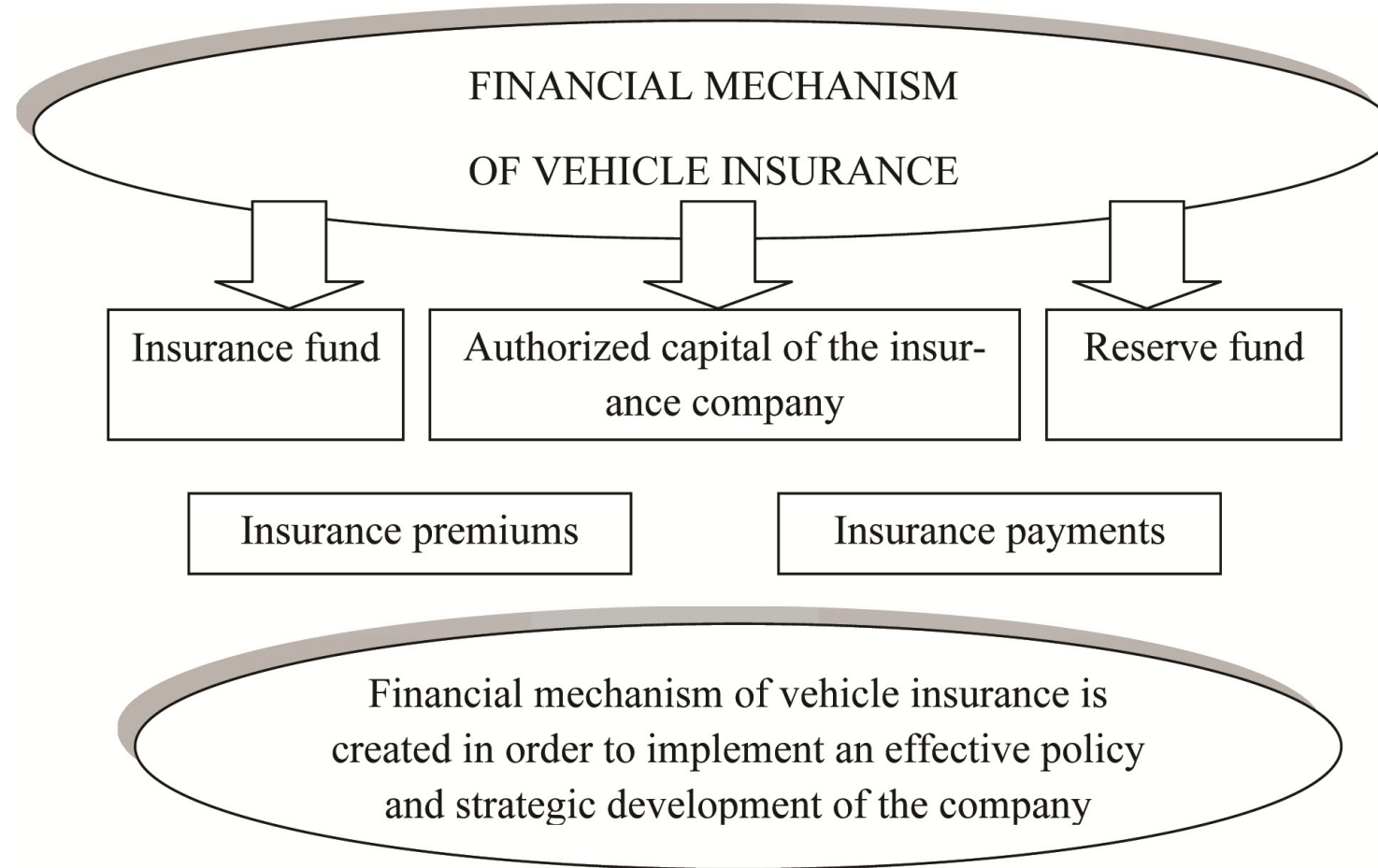

Figure 1. The structure of the financial mechanism for vehicle insurance

With regard to the authorized capital of the enterprise and reserve fund, we assign them to financial mechanism elements aimed at the functioning of the insurance company in the economic environment. Despite the fact that all these funds are formed within the organization, their function is directed to the external interaction with other economic subjects.

Firstly, the amount of share capital and reserve fund is controlled by an external regulator - the state.

Second, they form a financial guarantee of the company to its partners and insurants. The guarantee that the company has sufficient financial "cushion" to pay all creditors, contractors, insurants, to cover unforeseen damages and unprofitableness, but the additional capital and retained earnings can be used at the discretion of the founders. However, usually, these funds are directed to the further development of the enterprise.

Taking into account the modern definition of insurance financial mechanism, we shall define its content from several points of view.

From an economic perspective, the financial mechanism is an integral part of the economic mechanism, a set of financial incentives, levers, tools, forms, and methods for regulation of economic processes and relationships. The financial mechanism includes, first, prices, taxes, duties, privileges, fines, sanctions, grants, subsidies, bank loan and deposit interest rates, other interest rates, and tariffs.

From a financial perspective, the financial mechanism is a set of financial instruments and methods for regulation of economic processes and relationships. Set of financial relations methods organization forms for formation and use of financial resources used by the Company in order to create favourable conditions for economic and social development.

The financial and credit encyclopaedia considers financial mechanism as an integral part of the economic mechanism, provided a set of types and forms of financial relations organisation, conditions and methods of calculation used in the formation of financial resources, formation and use of designated funds. The financial mechanism is used to influence the economy and social sphere of uniform financial policy of the state, regions, municipalities, and businesses.

In our view, all of the above definitions of a financial mechanism reflect its essence, sense, and ways of working, as well as on what the work of the financial mechanism is directed and which elements include this tool. Thus, the financial mechanism of vehicle insurance is a set of tools with which the insurance company has the ability to influence its financial performance and build financial relationships within the enterprise, just as at vehicle 
insurance market, thereby ensuring its further development.

Vehicle insurance market in Russia is tightly regulated by the state in the context of financial mechanism for elements formation (size and structure of the authorized capital, amount, and method of reserve fund forming, method of forming insurance fund, basic tariff value in the case of OMI). State regulation of vehicle insurance assures that the market entry barriers are set high enough that will lead to the difficulty of entering the market for unscrupulous entrepreneurs. Following the appointment of the Bank of Russia on the role of a mega-regulator as of March 03, 2014, control over the activities of insurance companies will be strengthened to ensure early identification of the financial problems at the insurance company. To ensure financial stability and solvency of insurance companies, it is proposed to improve the quality of assets and own funds of insurance companies, to carry out a comprehensive risk assessment and adequacy of assets to fulfil the commitments made.

Insurance portfolio profitability of the insurance company is determined by the difference of revenues and expenditures. In the case of "vehicle insurance", the quality of claims settlement is the only tool controlled by the company having impact on insurance profitability. The more carefully this process is organized by the insurance company, the greater its chances of economic success.

In Russia, CNC and OMI are the most popular sales channels for insurance, but at the same time are the most unprofitable. Unprofitability for these types is up to $100 \%$. Recently, insurers are trying to cut costs at the time of sales, responding quickly to fluctuations in prices for repair of a particular model, as well as statistics of theft. No matter how good financial mechanism the company has, the dissonance can be brought by unfair and frankly fraudulent conduct of vehicle insurance market clients (fake car accidents, fictitious theft of insured vehicles).

Financial mechanism directly affects the result of the enterprise work. TO be exact, well-formed financial mechanism elements of the insurance company affect the economic performance of the company. One of the most important elements of insurance company's financial mechanism, affecting the economic results of the enterprise, is well-chosen insurance premium rate for each individual insurant.

Insurance premium rate consists of a base wage rate and ratio increase or decrease. Run-up in the rate value can range between 0.5-2.5. Unit means a base rate, used if the vehicle owner turned for the first time to the insurance company. In the future, if the insurant does not move from one company to another, then enhancing (for emergency driving) or lowering (premium for accident-free driving) rates apply.

Thus, the lowest premium may differ from the highest insurance premium for the same vehicle fivefold. Using increasing rates, insurance companies try to minimize their costs upon the occurrence of insurance events in the past.

Open Joint Stock Company "Insurance Company of Gas Industry" (SOGAZ, OJSC), established in 1995, is the successor of Closed Joint Stock Company "Euro-Asian Insurance Company of Gas Industry", whose founders in 1993 were the largest enterprises of Gazprom, OJSC. Insurance activities of SOGAZ, OJSC started in 1994 after the first license from Ministry of Finance of Russia. Based on the classic insurance types, SOGAZ, OJSC offers its clients a wide range of insurance products and programs.

SOGAZ, OJSC is licensed by the Federal Service for Financial Markets on the implementation of the 19 types of insurance and implemented on the basis of 115 of the Rules of insurance, reinsurance license, license by Office of FSS of Russia in Moscow and Moscow region for activities related to the use of information making a state secret, and the Russian Foreign Intelligence Service license to operate in the field of information security.

One of SOGAZ activities is to increase the volume of insurance through the mechanism of participation in tenders for insurance, including financed by federal and local budget funds.

An important event of 2012 was the increase in authorized capital from 8.04 billion of roubles to 15.11 billion of roubles, which further increased the financial stability of SOGAZ, OJSC. SOGAZ, OJSC as the parent company is included in the Insurance Group "SOGAZ". Insurance group "SOGAZ", in addition to SOGAZ, OJSC, currently includes the following companies: SOGAZ-ZHIZN, IC LLC, SOGAZ-MED, IC OJSC, SOGAZ-AGRO, IC LLC, International Medical Centre SOGAZ, LLC, Lider, LLC, and SOGAZ-Medservis, CJSC. The companies of the Group have unified management, general system of sales and service, regional network consisting of more than 600 branches, as well as sales offices located in more than 80 regions of the Russian Federation. Only SOGAZ, OJSC has now open and operating 72 branches and 81 divisions located in 74 regions of the Russian Federation. Table 1 shows SOGAZ, IC dynamics for OMI premium received and payments made in 2011-2013 in Russia in general. 
Table 1. Dynamics of SOGAZ, IC indicators on OMI agreements in the Russian Federation for 2011-2013

\begin{tabular}{llllllll}
\hline Year & Revenues & \multicolumn{5}{c}{ Payments } & $\begin{array}{l}\text { Payout } \\
\text { ratio,\% }\end{array}$ \\
\cline { 2 - 6 } & $\begin{array}{l}\text { Place in the } \\
\text { ranking among } \\
\text { all insurers }\end{array}$ & $\begin{array}{l}\text { Revenues } \\
\text { (thous. } \\
\text { roubles). }\end{array}$ & $\begin{array}{l}\text { \% from the } \\
\text { previous } \\
\text { year rate }\end{array}$ & $\begin{array}{l}\text { Place in the } \\
\text { ranking } \\
\text { among all } \\
\text { insurers }\end{array}$ & $\begin{array}{l}\text { Payments } \\
\text { (thous. } \\
\text { roubles). }\end{array}$ & $\begin{array}{l}\text { \% from the } \\
\text { previous } \\
\text { year rate }\end{array}$ \\
\hline 2011 & 16 & 1150740 & 114.02 & 16 & 521222 & 107.93 & 45.29 \\
2012 & 16 & 1441345 & 125.25 & 16 & 521954 & 100.14 & 36.21 \\
2013 & 13 & 2517042 & 174.63 & 16 & 732470 & 140.33 & 29.10 \\
\hline
\end{tabular}

The insurance company has a stable position in the Russian insurance market, which especially strengthened for the year 2013 - the company ranked 13th in Russia in terms of revenues.

With regard to the status and image of SOGAZ, IC at the vehicle insurance services market, it is in the TOP-20 in terms of insurance premiums received by main vehicle insurance types - OMI and CNC.

Table 2 shows SOGAZ, IC dynamics for OMI premium received and production payments made in 2011-2013. in the Sverdlovsk region.

Table 2. Dynamics of SOGAZ, IC indicators on OMI agreements in the Sverdlovsk region for 2011-2013

\begin{tabular}{|c|c|c|c|c|c|c|c|}
\hline \multirow[t]{2}{*}{ Year } & \multicolumn{3}{|l|}{ Revenues } & \multicolumn{3}{|l|}{ Payments } & \multirow{2}{*}{$\begin{array}{l}\text { Payout } \\
\text { ratio,\% }\end{array}$} \\
\hline & $\begin{array}{l}\text { Place in the } \\
\text { ranking among } \\
\text { all insurers }\end{array}$ & $\begin{array}{l}\text { Revenues } \\
\text { (thous. } \\
\text { roubles). }\end{array}$ & $\begin{array}{l}\% \text { from the } \\
\text { previous } \\
\text { year rate }\end{array}$ & $\begin{array}{l}\text { Place in the } \\
\text { ranking } \\
\text { among all } \\
\text { insurers }\end{array}$ & $\begin{array}{l}\text { Payments } \\
\text { (thous. } \\
\text { roubles). }\end{array}$ & $\begin{array}{l}\% \text { from the } \\
\text { previous } \\
\text { year rate }\end{array}$ & \\
\hline 2011 & 19 & 39545 & 119.52 & 20 & 21729 & 96.32 & 54.95 \\
\hline 2012 & 18 & 48833 & 123.49 & 19 & 17863 & 82.21 & 36.58 \\
\hline 2013 & 16 & 73526 & 150.57 & 20 & 22059 & 123.49 & 30.00 \\
\hline
\end{tabular}

Based on the data presented in Tables 1 and 2, it can be concluded that the company is constantly increasing its presence in OMI market. This is evidenced by the growth of insurance premiums. For example, in 2013, insurance premiums amounted to $218.73 \%$ as compared to 2011 in the Russian Federation (from 1,150,740 thousand roubles to 2,517,042 thousand roubles), allowing SOGAZ, IC to climb from the 16th place to the 13th. In the Sverdlovsk region, the figure was slightly less- $185.93 \%$ (from 39,540 thousand roubles to 73,256 thousand roubles), which allowed the company to increase its presence in the regional market and to rise from the 19th place to the 16th. As for insurance payments, the figure is growing in both the Russian Federation and the Sverdlovsk region. According to the Russian Federation in 2013, this figure amounted to $140.53 \%$ compared to 2011 (22,521 thousand roubles to 732,470 thousand roubles). In the Sverdlovsk region it amounted to 101.52\% over the same period (from 21,729 thousand roubles to 22,059 thousand roubles).

It can be seen that the growth rate of insurance premiums are outpacing growth insurance payments as the whole of Russia, and in some regions, e.g. the Sverdlovsk region, which cannot have a positive effect on the financial condition of the insurance company.

Similar analysis is applied to the presence of SOGAZ, IC at the vehicle insurance market of CNC of the Russian Federation and the Sverdlovsk region. Table 2 shows SOGAZ, IC dynamics for CNC premium received and payments made in 2011-2013 in the Russian Federation. 
Table 3. Dynamics of SOGAZ, IC indicators on CNC agreements in the Russian Federation for 2011-2013

\begin{tabular}{llllllll}
\hline Year & Revenues & \multicolumn{5}{c}{ Payments } & $\begin{array}{l}\text { Payout } \\
\text { ratio,\% }\end{array}$ \\
\cline { 2 - 8 } & $\begin{array}{l}\text { Place in the } \\
\text { ranking } \\
\text { among } \\
\text { insurers }\end{array}$ & $\begin{array}{l}\text { Revenues } \\
\text { (thous. } \\
\text { roubles). }\end{array}$ & $\begin{array}{l}\text { \% from the } \\
\text { previous } \\
\text { year rate }\end{array}$ & $\begin{array}{l}\text { Place in the } \\
\text { ranking among } \\
\text { all insurers }\end{array}$ & $\begin{array}{l}\text { Payments } \\
\text { (thous. } \\
\text { roubles). }\end{array}$ & $\begin{array}{l}\text { \% from the } \\
\text { previous } \\
\text { year rate }\end{array}$ \\
\hline 2011 & 15 & 2605441 & 123.95 & 17 & 1302668 & 96.73 & 50.00 \\
2012 & 12 & 4587759 & 176.08 & 15 & 1736010 & 133.27 & 37.84 \\
2013 & 11 & 6488948 & 141.44 & 13 & 2890440 & 166.50 & 44.54 \\
\hline
\end{tabular}

Table 4 shows SOGAZ, IC dynamics for CNC premium received and payments made in 2011-2013 in the Sverdlovsk region.

Table 4. Dynamics of SOGAZ, IC indicators on CNC agreements in the Sverdlovsk region for 2011-2013

\begin{tabular}{llllllll}
\hline Year & Revenues & \multicolumn{5}{c}{ Payments } & $\begin{array}{l}\text { Payout } \\
\text { ratio,\% }\end{array}$ \\
\cline { 2 - 6 } & $\begin{array}{l}\text { Place in the } \\
\text { ranking } \\
\text { among } \\
\text { insurers }\end{array}$ & $\begin{array}{l}\text { Revenues } \\
\text { (thous. } \\
\text { roubles). }\end{array}$ & $\begin{array}{l}\text { \% from the } \\
\text { previous } \\
\text { year rate }\end{array}$ & $\begin{array}{l}\text { Place in the } \\
\text { ranking among } \\
\text { all insurers }\end{array}$ & $\begin{array}{l}\text { Payments } \\
\text { (thous. } \\
\text { roubles). }\end{array}$ & $\begin{array}{l}\text { \% from the } \\
\text { previous } \\
\text { year rate }\end{array}$ \\
\hline 2011 & 19 & 70267 & 76.78 & 24 & 28626 & 63.14 & 40.74 \\
2012 & 17 & 120861 & 172.00 & 21 & 38681 & 135.13 & 32.00 \\
2013 & 13 & 217544 & 180.00 & 16 & 92643 & 239.51 & 42.59 \\
\hline
\end{tabular}

Tables 3 and 4 show that the presence of SOGAZ, IC at the vehicle insurance market of CNC of the Russian Federation is significantly higher than in OMI market. In RF, SOGAZ, IC ranks 11th on the amount of insurance premiums and 16th on the amount of insurance payments. In the Sverdlovsk region, SOGAZ, IC ranks 13th and 16th places respectively.

Income from insurance premiums in the Russian Federation (Table 3) in 2013 amounted to $249.05 \%$ as compared to 2011 (from 2,605,441 thousand roubles to 6,488,948 thousand roubles), in the Sverdlovsk region (Table 4), this rate is $309.59 \%$ (from 70,267 thousand roubles to 217,544 thousand roubles). The amount of insurance premiums in 2013 compared to 2011 in Russia amounted to $221.89 \%$ (from 1,302,668 thousand roubles to $2,890,440$ thousand roubles). In the Sverdlovsk region, the similar figure is $323.63 \%$ (from 28,626 thousand roubles to 92,643 thousand roubles).

Percentage of insurance premiums received by SOGAZ, IC in 2013 in the Sverdlovsk region amounted to 3.23\% of all insurance premiums received by SOGAZ, IC for all subjects of the Russian Federation under CNC and OMI insurance. The comparable figure in 2011 amounted to 2.92\%.

Table 5 shows SOGAZ, IC rating in Yekaterinburg relative to other market participants on CNC vehicle insurance market for 2013. 
Table 5. Indicators of SOGAZ, IC on CNC agreements in Yekaterinburg for 2013

\begin{tabular}{|c|c|c|c|c|c|c|c|}
\hline \multirow[b]{2}{*}{ Year } & \multicolumn{3}{|l|}{ Revenues } & \multicolumn{3}{|l|}{ Payments } & \multirow[b]{2}{*}{$\begin{array}{l}\text { Coef. of } \\
\text { payment } \\
\%\end{array}$} \\
\hline & $\begin{array}{l}\text { Place in the } \\
\text { ranking } \\
\text { among all } \\
\text { insurers }\end{array}$ & $\begin{array}{l}\text { Revenues } \\
\text { (thous. } \\
\text { roubles). }\end{array}$ & $\begin{array}{l}\% \text { from the } \\
\text { previous year } \\
\text { rate }\end{array}$ & $\begin{array}{l}\text { Place in the } \\
\text { ranking } \\
\text { among all } \\
\text { insurers }\end{array}$ & $\begin{array}{l}\text { Payments } \\
\text { (thous. } \\
\text { roubles). }\end{array}$ & $\begin{array}{l}\% \text { from the } \\
\text { previous year } \\
\text { rate }\end{array}$ & \\
\hline 2013 & 14 & 84519 & 134 & 14 & 39802 & - & 47 \\
\hline
\end{tabular}

Based on the presented data, it can be concluded that SOGAZ, OJSC strengthened its position in the vehicle insurance market during the last three years quite successfully, in both Russia, Sverdlovsk region, and directly in Yekaterinburg. At that, the company managed to maintain a positive balance between insurance premiums and payments on insured events.

According to the authors, one of the major challenges for secure vehicle insurance in Russia is bad faith of some insurers in terms of compliance with the Federal Law "On the organization of vehicle insurance". Compliance failure is in the lack of reserve funds formation, insurance funds, and share capital insufficiency. Accordingly, when the need for large payments to insurants arises, the company is unable to meet all its obligations. Therefore, in 2014, reduction of the insurance market players is expected. As a rule, small companies will leave the market that cannot withstand tougher rules of the game.

By the end of 2013, the five leaders of the insurance market in terms of insurance premiums were as follows: "Rosgosstrakh", "SOGAZ", "Ingosstrakh", "Reso-Garantiya", and "Soglasiye". According to the National Rating agency, leadership in OMI sales belongs to the following companies: "Rosgosstrakh", "Reso-Garantiya", "Ingosstrakh", "Insurance Group "MSK","VSK".

Of course, that various practical driver's examples will help to make the choice of a particular insurance company, as well as give an opportunity to make the right decision when choosing OMI insurance. Modern vehicle owner needs to know and understand the dynamics of prices in the insurance market, factors influencing formation of prices for $\mathrm{OMI}$ and $\mathrm{CNC}$ policies, as well as other vehicle insurance forms. It is important to know the mechanisms used by the insurance companies at their activities, as well as ways of influencing them in order to obtain adequate compensation for the insured event.

The second problematic vehicle insurance factor in Russia, as seen by the authors, is discrepancy of existing insurance rates and insurance payments (OMI insurance policies).

According to the data provided by the National Rating Agency, the compulsory vehicle insurance segment in 2013 was the most problematic. OMI premiums increased by $10.3 \%$ to 134.25 billion of roubles with a simultaneous increase in payments by $19 \%$ ( 77.37 billion of roubles). In 2013, 42.43 million OMI insurance agreements were signed (in 2012 - 40.4 million of agreements).

Tensions in OMI market that emerged in 2012 because of changes in judicial practice, application of Law on Consumer Protection Rights in insurance, increased significantly in 2013. The combination of these factors with a high level of fraud and the absence of any decision by the government resulted in market self-regulation, which, in turn, resulted in reduction by major insurers of their presence in this segment. Thus, the volume of premiums for Ingosstrakh, OJSIC has decreased by $20 \%$, for Rosgosstrakh, LLC - by $12 \%$. If the three largest OMI insurers in 2012 accounted for more than $50 \%$ of premiums, then in 2013 they accounted only for $42.24 \%$. According to the National Rating Agency, the top ten insurers account for $75.6 \%$ of premiums (in $2012-78.81 \%$ ), the top twenty- $89.45 \%$ (in $2012-90.46 \%$ ).

Public vehicle insurance terms do not give companies the right to refuse signing agreements. Insurance companies, in fact, act as insurance agents in this insurance type, and the guarantor role is performed by the state. Thus to decrease sales in certain regions, insurers use deterioration in the terms of unprofitableness settlement (settlement points transfer to remote populated places), entering into agreements with "load" in the form of additional voluntary insurance policies, prerecord. In 2013, dramatically increased the number of complaints about such cases.

The above-mentioned analytical data and results are radically contrary to all insurance principles. It turns out that the parties are forced to engage in economic relations without trust to each other, It is good when during period 
of the vehicle insurance agreement there were no insured events, and the parties have no mutual claims. However, in case of insured event, the litigation between the insurer and the insurant starts for payment, and, as a rule, all these relationships end up in court. In addition, the court is mostly on the side of the vehicle owner.

On the one hand, vehicle owners do not take into account wear of vehicle's parts and expect excessive amount of payment.

On the other hand, vehicle insurers are trying in every way to understate the amount of loss to maintain their margins. Many insurance companies have their own experts and service stations in which repair will be much cheaper than made by the authorized dealer. However, as the Russian practice demonstrates, all of these additional services of the insurance company are aimed at understating the amount of damage, instead of being aimed at saving client's time.

Thus, appraisers are assessing the damage based on the interests of insurance companies, while service centres, in turn, cannot cope with the flow of clients from the insurance company and the time allocated to work with a particular client, which leads to poor quality of work, client complaints, and long queues. It is clear that in a market economy, the actions of all agents are aimed at making profit and minimizing costs. The same is here, where the main criterion for selection is the price. The one with the lowest price will get the agreement. However, in practice, this transforms into poor quality of work and use of cheap consumables. It is hard to find a service station quite loyal to the insurance company and providing quality services at low cost. The insurers say that the most unprofitable sector in $\mathrm{CNC}$ is small, but numerous damages. Clients often seek support in preserving the car in perfect presentation through insurance. They are trying to claim for repair of the smallest chips and scratches. Vehicle owners tend to settle even minor works at service stations from an authorized dealer, where prices are much more expensive. Effective methods to direct the vehicle owner to get repair at the multi-branded service station do not (except for performance speed). This is due to the lack of economic benefits, in addition, the insurant fears that the vehicle will lose the guarantee. Although none of the dealers will not confirm in writing that the vehicle will be removed from the guarantee due to the replacement of the bumper or scratches. However, vehicle owners behaviour has a downside. Of course, one may not apply to the insurer for repair of each scratch and chip, but when there is a serious insurance case with significant damage, the insurance company has the right to refuse in full or in part to compensate the damage, because the vehicle already contains older damages. Those vehicle owners who have been in this situation and faced with incomplete claims, one for each insignificant matter will contact the insurance company and keep their vehicle in the presentation, insuring themselves thereby from the non-payment of insurance compensation at a more serious accident, but it is not so beneficial for the insurer. Insurers themselves point to the same dishonest costs reduction methods. These ungrounded comments to documents from law enforcement bodies, understating the amount of calculation and use of poor quality, but cheap service stations.

Creating a common standard is necessary, first, to deal with unscrupulous companies that use low literacy rate and provide poor quality insurance services. Single standard will include several standards common to all market participants. In particular, insurance companies will be required to indicate in the policy period for making payments. For delay in payments, the insurer will be liable to the supervisory authorities. In addition, CNC standard will fix a list of documents to be submitted for reimbursement. The company will not be entitled to claim additional documents.

Another item of the new rules will be the unified methodology to assess damage. It is planned to develop an overall system for assessing damages caused to vehicle owners. This will allow protecting citizens against manipulation by unscrupulous insurers. In addition, unified methodology will facilitate transactions between insurance companies and reduce load of courts.

As of January 01, 2013, the insurance company under RAMI leadership agreed to introduce the Automated Information System OMI (AIS OMI), where all insurance companies will compulsorily add insurance history of all their clients for the last 2 years, as well as all new sold OMI and payments on OMI insurance events within 15 working days. When selling a new OMI policy, an insurance agent is obliged to check the client history based on AIS OMI.

Firstly, CNC is really becoming unprofitable so, that conscientious companies are forced to minimize their risks. Honest customers and agents suffer with them as well.

Secondly, it is clear that scammers feel particularly at ease in the regions where insurance market transparency is not ensured and where no interaction to verify potential insurants.

Vehicle owners who get into an accident, cannot save money at transition from one insurance company to 
another. Vehicle Insurers Protection Association proposed the creation of a unified CNC client base as insurers know the story of their vehicle insurants only from the time when they become their clients, and do not have information about their past.

Unscrupulous drivers, using this, several times make insurance cases during the agreement validity, receive substantial payments, and then go to another company and make $\mathrm{CNC}$ without raising factors. Insurers bear financial losses, and vehicle owners avoid responsibility.

One of the factors to improve the situation would be to create a unified CNC database. Its creation will not be difficult, believes the association. It is sufficient to use the existing bonus-malus coefficients database for OMI. This system contains comprehensive information on drivers. The only thing remained is to add information about CNC Insurance. "Taking care of own insurance history, insurers will reduce the number of requests for minor damages. Interest in franchise will increase. Overall unprofitableness ratio of this type of insurance will decrease.

As for the adjustment of OMI basic tariffs, then considering the entire difficult situation in vehicle insurance market, the mega-regulator, Central Bank proposes to raise OMI tariffs by $19-24 \%$. According to the information received by "Kommersant", according to the actuarial valuation carried out by an independent consulting and actuarial agency commissioned by the Bank of Russia, the basic insurance rates shall be increased by $18.9-23.6 \%$.

Central Bank offers to increase insurance cost simultaneously with increase on payments limits to property and life in two stages. Thus, until June 01, 2014 payment on the property shall be increased to 400 thousand roubles "simultaneously with the first stage of tariff adjustments". Central bank does not specify rate increase amount.

The second stage is increasing payments on the life and health of road traffic accidents victims to 500 thousand roubles with another increase in tariffs. Central Bank proposes to hold it until July 01, 2015. By the same date, according to the regulator, OMI shall be sold electronically.

According to the calculations of the Russian Association of Motor Insurers, the present basic rates shall be raised by 40 percent. (Note 1 )

Positive expectations of vehicle insurers in 2014 are related to the increase in tariffs, creation of a unified method for determining damage, while negative are related to an increase in tariffs, payments limits, and unlimited euro-protocol expansion.

\section{Method}

Based on this analysis, the authors propose a new method to improve insurance portfolio profitability and reduce unprofitableness ratio of the main insurance types (OMI and $\mathrm{CNC}$ ).

The method is called "Improving vehicle insurance profitability based on client-oriented approach". The name symbolizes honesty and integrity of all insurance market participants (insurers and insurants), which can be achieved through transparency of insurance companies work, understanding insurance premiums formation mechanism and reduced unprofitableness of basic vehicle insurance types-OMI and CNC.

The purpose of the method "Improving vehicle insurance profitability based on client-oriented approach" is to reduce unprofitableness ratio of the main vehicle insurance types and increase insurance portfolio profitability.

The main objectives of the method include:

- Definition of the target segment for vehicle insurance products sales;

- Definition of sales channels for the company's insurance products on the risk reduction principle;

- Development of financing and coefficient component methods, used for a particular insurant.

Conceptual framework. Client focus is a company's ability to extract additional profit from deep understanding and meeting different client needs. Client-oriented approach means a set of measures aimed at addressing the needs of clients and creation of a product with as much as possible view to profit.

Target segment is one of the market segments selected as the primary for the realization of the company's objectives (the company's products).

Sales channel is a way of clients receipt to the company having certain characteristics or mode of the insurance product delivery to a client.

Financing method is a way of financial flows receipt in the company from the funding source.

Advantages of the author's method are in the development of rules and regulations to make the vehicle insurance 
system more transparent. This will allow vehicle insurant to obtain the correct expectations on insurance payments, i.e. have an exact view of financial consequences. The insurant will be able to navigate in the selection of insurance programs, understand insurance premiums size, and understand insurance benefits amount, depending on the variety of the insured event and the selected tariff. The method of "Improving vehicle insurance profitability based on client-oriented approach" is aimed at combating fraudulent actions on the part of insurants by identifying frauds at the first stage of insurance. In turn, the insurance companies do not have to understate artificially the amount of insurance payments to reduce own unprofitableness. Accordingly, effectiveness from use of raised insurance premiums increases.

Schematically, the contents of the method "Improving vehicle insurance profitability based on client-oriented approach" is shown in Figure 2.

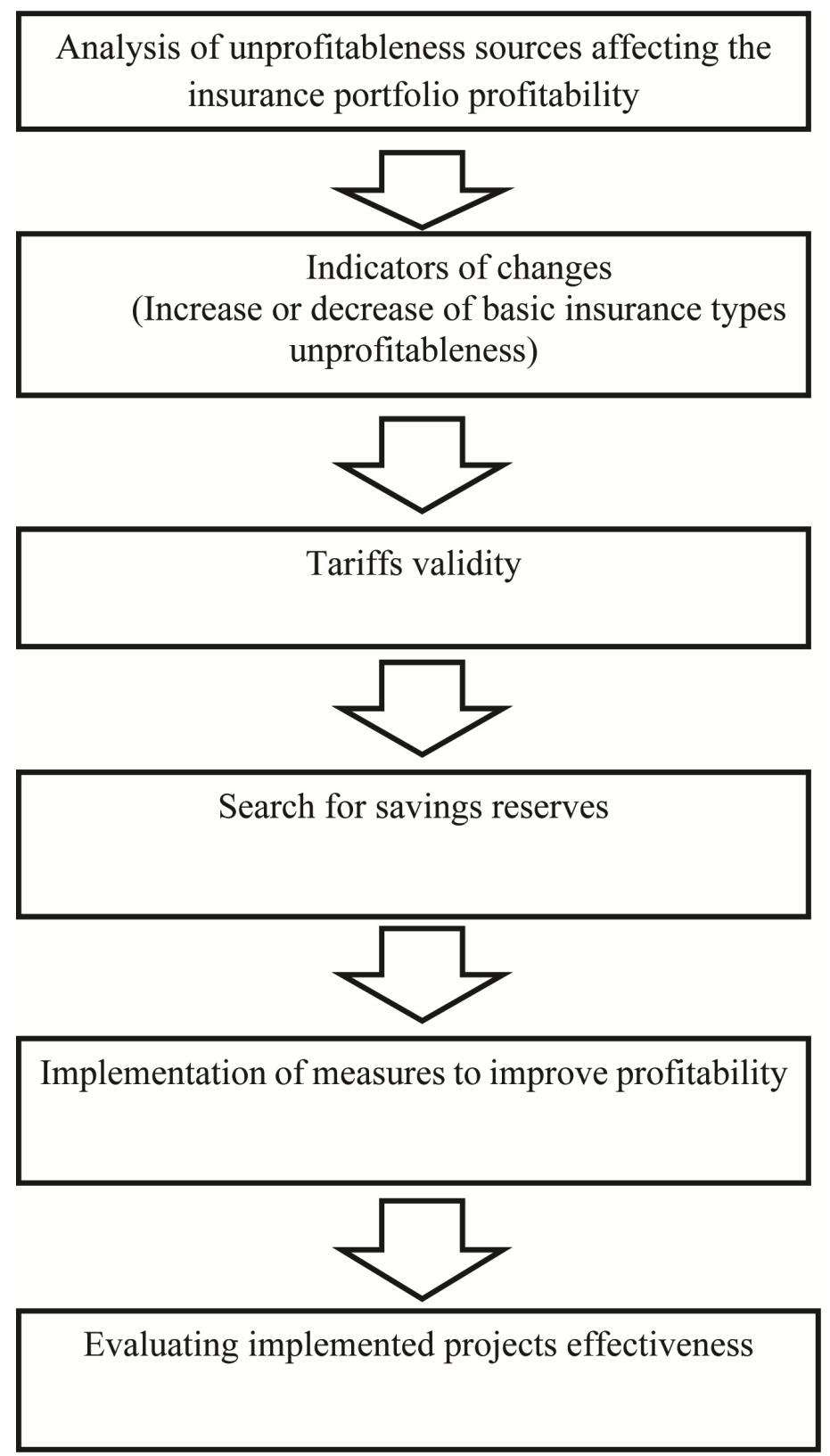

Figure 2. Staged building of "Improving vehicle insurance profitability based on client-oriented approach" method

Stage 1. Analysis of unprofitableness sources affecting the insurance portfolio profitability

The main sources of vehicle insurance unprofitableness can be: 
- Certain sales channels of insurance products;

- Excess of vehicle insurance products share in IC insurance portfolio;

- Certain categories of vehicles.

To determine the sources, first, it is necessary to analyse sales channels on the unprofitableness criterion. The following main sales channels are distinguished: office, agent (through insurance agents and insurance brokers), showroom (through car dealerships). The safest sales channel is office, because employees of the company can determine the category of the client and make a thorough inspection of the vehicle.

The riskiest channel is agent, as agents are attracted persons who are not employees of the insurance company and who receive a commission for their services. Accordingly, in order to increase their earnings, they need to sell more insurances, attracting more clients. Less risky channel than the agent, are showrooms. Showrooms are still focused on the sale of insurance for new cars, which is CNC in majority, but also they sell insurance for used cars purchased outside the showroom.

The second risk source includes vehicle insurance share in the insurance portfolio. At excess the set secure limit on attracting vehicle insurance clients, overall insurance portfolio profitability reduces upon the occurrence of insurance events for major damage or theft of the vehicle. The third source of unprofitableness implies vehicles categories. This source can be both the most profitable and the most unprofitable because insurance payments may sufficiently exceed premiums. In case if the insured event does not occur, the insurance premium remains in IC.

Stage 2. Indicator of changes means a system of indicators based on which it is possible determine insurance portfolio dynamics, i.e., increase or decrease in the basic insurance types unprofitableness. There are the following types of indicators:

- Sales channels unprofitableness;

- Vehicles categories unprofitableness;

- Risks unprofitableness (damage, theft, embezzlement);

- Client unprofitableness.

Tracking unprofitableness dynamics on these parameters, it is possible to react quickly to changing situation. For example, analysing vehicle insurance unprofitableness dynamics in agent insurance portfolio, it is possible to quickly respond to the unprofitableness growth, i.e. to reduce vehicle insurance share in insurance portfolio or prohibit OMI sales to the agent. It may also be expressed in reduction of certain sales channels (agent and showroom) and in strengthening office sales. At a higher incidence of certain vehicles brands thefts, the insurance company, reducing their risks, may increase insurance rates, raise franchise or prohibit insurance of this vehicle model (last resort). At increased risk of vehicles theft in a particular region, the insurance company may increase insurance rate and (or) reduce the presence of the region in the insurance company's portfolio. The next very important factor is client unprofitableness. When insured event is often for one insurant and insurance payments exceed $50 \%$ of the insurance premium, the insurance company has the right not to prolong the insurance agreement with the unprofitable customer for the next year, or apply a bonus-malus coefficient with an increase in insurance premiums for the next year to $80 \%$. With the introduction of a united CNC and OMI insurants database, the client will not able to go to another company with a lower insurance rate.

Stage 3. Tariffs validity. To introduce valid tariffs, it is necessary to analyse spare parts market, repairs market (vehicle service station repairs cost), insured event occurrence probability. This analysis is necessary in order to identify weak regions and regions with high risk of theft or damage. More risky regions may include regions with dense traffic movement, and regions with high incidence of vehicle theft and additional equipment. These regions will have increased insurance rates. With regard to spare parts and repairs market analysis, it is necessary to be conducted to determine insurance rates for various vehicles models to let insurance payments cover the necessary repairs. It is worth noting that the insurance payment for "damage" will be carried out taking into account wear and tear of vehicle spare parts and the insurant shall be ready for this.

Stage 4. Search for savings reserves. After analysing the constituent elements of the above blocks of the provided matrix, the insurance company shall identify the sources of savings. According to authors, these sources include:

- Reduction of intermediary unprofitable sales channels of insurance products;

- Development of office sales;

- Maintaining a clear structure of the insurance portfolio; 
- Rejection of unprofitable customers;

- Rejection of certain vehicles insurance types;

- Reducing the number of retail customers and increasing corporate clients share.

Let us analyse in detail the consequences of each item.

Reduction of intermediary unprofitable sales channels of insurance products. After analysing insurance brokers performance, unprofitable brokers shall be identified. Unprofitable are those brokers whose unprofitableness on the main insurance types exceeds 50\%. Risk insurance brokers group include those with vehicle insurance unprofitableness ratio of $30 \%-50 \%$. The insurance company has the right to terminate the agent agreement with such agents or send them recommendations to remedy the situation, thereby reducing their risk of vehicle insurance fraud.

Reducing the number of retail customers and increasing corporate clients share. These two factors are, in fact, inseparable. By developing these two areas, the insurance company reduces its risks to attract scammers and insurants with a high-risk degree. Firstly, when the client itself comes to the sales office, (s)he will communicate with a concerned - an employee of the company. Second, thorough visual inspection of the vehicle will be carried out. Third, the employee will be able to identify the client's risk degree and offer him adequate tariff rate. By attracting corporate clients, the insurance company provides itself with constant increase in insurance premiums and annual prolongation of existing agreements.

Maintaining a clear structure of the insurance portfolio. This savings criterion primarily relates to agent and showroom sales channels. At insurance agent unprofitableness on the basic insurance types exceeding $50 \%$, vehicle insurance share in the insurance portfolio may not exceed $20 \%$. At insurance agent unprofitableness on vehicle insurance in the insurance portfolio of $30 \%-50 \%$, vehicle insurance share shall not exceed $30 \%$. At insurance agent unprofitableness on vehicle insurance in the insurance portfolio of less than $30 \%$, vehicle insurance share shall not exceed $40 \%$ of all insurance types sales. Showroom sales can be regulated only in OMI. Limitation in this sales channel implies that OMI will be sold only to those customers whose vehicles are purchased in the showroom.

Rejection of unprofitable customers. The author offers to abandon completely unprofitable clients, whose insurance payments exceeded $50 \%$ of the insurance premium and amounted to more than three times during the reporting period or apply bonus-malus coefficient to such clients by which the insurance rate may be increased to $80 \%$ of the original amount. With the introduction of a unified insurants database on CNC and OMI, move from one company to another without raising factors will be impossible. This measure sufficiently disciplines irresponsible drivers and increase the profitability of IC main vehicle insurance types.

Rejection of certain vehicles insurance types. The company reserves the right to refuse insurance of unfavourable vehicle categories. Higher risk categories include second-hand foreign cars older than 4 years, passenger cars of domestic production, cars popular among car thieves, having no additional anti-theft system. The company may refuse to insure a used foreign car without knowing its history.

Reducing number of retail customers. This criterion of savings will help to reduce the risks at providing an insurance to a client with unknown insurance history.

Stage 5. Implementation of measures to improve profitability. After analysing sales channels, insurance agents profitability, auto insurance products unprofitableness in the regional markets, unprofitableness of certain vehicles types, customers unprofitableness, etc., we shall move directly to the development and implementation of specific measures to improve profitability.

The necessary activities are the following:

1) Reduce the proportion of agency and showroom sales in IC sales structure to $30 \%$.

2) Terminate agreements with insurance agents whose unprofitableness on vehicle insurance products exceeds $80 \%$.

3) Allow showrooms to sell OMI for vehicles purchased from them only.

4) OMI share in vehicle insurance portfolio may not exceed $20 \%$ of all vehicle insurance acquisitions.

5) Deny vehicle insurance agreement prolongation with clients for whom payments amounted to more than $50 \%$ of the paid insurance premium or insured events occurred more than three times per year. This condition does not apply to corporate clients. 
6) Prohibit $\mathrm{CNC}$ vehicle insurance in risky regions of the Russian Federation from theft for vehicles without two additional anti-theft systems installed.

7) Prohibit used vehicles insurance older than 4 years. Used vehicles of foreign manufacture are permitted to insure by prolonging the low unprofitable vehicle insurance agreement (insurance compensation shall not exceed $50 \%$ of the paid insurance premium). These conditions do not apply to clients participating in the corporate vehicle insurance.

8) In the case of an insured event on the risk of "damage", the car shall be sent for repairs to the vehicle service station of the insurance company where average statement on spare parts shall be made taking into account the percentage of vehicle wear.

9) In the case of "vehicle destruction", vehicle salvage materials shall be eliminated by the insurance company and the payment shall be made.

10) The insurance agreement shall necessarily have the amount of unconditional franchise specified of at least $2 \%$ of the insurance premium.

11) Increase the share of corporate sales to $60 \%$ of the acquisitions of all the insurance premiums from vehicle insurance.

12) Bring all these activities to each employee of the company through appropriate regulations.

Stage 6. Evaluating the effectiveness of the activities implementation. Performance indicators in this method are:

- Reduced unprofitableness in vehicle insurance in the insurance services portfolio of the insurance company;

- Qualitative change in the structure of IC clients for vehicle insurance;

- Increased profitability of the insurance portfolio.

\section{Results}

After the introduction of the "Increased vehicle insurance profitability based on client-oriented approach" method, the company shall face a qualitatively change in the client base structure. The method aims to reduce the retail sale of insurance products, increase legal entities presence. In addition, the method focuses on signing OMI and $\mathrm{CNC}$ insurance agreements with corporate clients. This will significantly reduce the risk of fraud on the part of the client. Office sales channels share is increased, corporate insurance program is developed. The emphasis from agency sales channels is notedly shifted to $30 \%$ of presence. The structure of agency sales has significantly reduced number of agents with motor insurance type unprofitableness above $80 \%$. Prohibition to sign new insurance agreements in CNC and OMI unprofitable regions and the possibility of prolonging old agreements with low unprofitable clients significantly reduce unprofitableness in these directions. Shortage of insurance agreements on direct sales markets for individuals is supposed to be replaced with the corporate insurance and increase in the presence of legal entities. The insurance company has the possibility to control their unprofitableness upon the occurrence of insurance events under "Damage" article by a detailed analysis of the spare parts market and their vehicle service stations. In the case of "vehicle destruction", the insurance company has the possibility to sell the salvage materials in a more favourable way. The complex of all the activities and results will lead to a reduction in vehicle insurance unprofitableness and, as a result, will increase the insurance portfolio profitability.

\section{Discussion}

In conclusion, it would be good to note the following: the scientific article identifies the barriers to safe vehicle insurance in the national economic system, both for the vehicle insurance market organizers and consumers of these services. Both insurance companies and state regulators understand these factors. Therefore, the state activity is directed, on the one hand, on tightening control measures for insurance companies to protect insurance consumers from unreliable insurers. On the other hand, the insurers are tightening the criteria for insurants selection and revise tariffs calculations. In addition, the context of the vehicle insurance financial mechanism contains the method aimed at increasing profitability of vehicle insurance based on the client-oriented approach.

\section{Acknowledgments}

The team of authors expresses sincere gratitude to Galushin Nikolay Vladimirovich, Kovaleva Tatyana Vladimirovna, Seleznev Kirill Vladimirovich, and Melnikov Andrey Sergeyevich — the specialists of "SOGAZ" insurance group for providing a representative sample of analytical data on insurance operations in the framework of the scientific research. 


\section{References}

Akhvlediani,Y. T. (2011). Insurance (2nd ed. p. 567). UNITY.

Aliev, B. H. (2014). Insurance Basics: Educational book (p. 503). M.: UNITY-DANA.

Arkhipov, A. P. (2012). Insurance (p. 288). KnoRus. http://dx.doi.org/10.15216/9785406013724

Babenko, I. A., Badyukov V. F., \& Zhuk I. N. (2011). Evaluation of the investment cost of the insurance company at mergers and acquisitions (p. 284). M.: Ankil.

Bespalov, M. S. (2012). Insurance premiums: Accruals, payments, accounting (p. 176). KnoRus.

Blau, S. L., \& Romanov, Y. A. (2014). Foreign economic activity insurance (p. 176). M.: PTC Dashkov and Co.

Chaldaeva L. A., \& Chernov M. A. (2014). Regional vehicle insurance markets: Current state and development prospects. Finance and credit, 38.

Denisov, D. V., \& Kotlobovskiy, I. B. (2013). Actuarial calculations in life insurance: A training textbook (p. 126). M.: Publishing house of the Moscow University.

Heydema, J. M. (2012). Fascinated agent (p. 272). M.: Infotropik Media.

Krichevskiy, M. L. (2012). Financial risks: Textbook (p. 248). M.: KNORUS.

Kryukov, R. V. (2012). Insurance (p. 159). M.: Publishing house A-Prior.

Pinkin V. S. (2012). Insurance and receiving insurance payments (p. 96). Publishing house Omega-L.

Roik, V. D. (2013). Economics, finance and social insurance law: Institutions and insurance mechanisms (p. 257). M.: Alpina Publisher.

Rusetskaya, E. A., \& Shakhbiev, M. T. (2012). Insurance in the Russia economic security system (p. 168). M.: Publishing house Ankil.

Samarov, E. K. (2011). Insurance mathematics: practical course: Textbook (p. 80). M.: Alpha-M, INFRA-M.

Sokol, P. M. (2013). Compulsory insurance of civil liability for vehicle owners (p. 168). M.: Publishing house "Delovoy Dvor".

Shapkin, A. S. (2012). Economic and financial risks: Assessment, management, investment portfolio (p. 544). M.: Publishing and trading Corporation Dashkov and Co.

Shikhov, A. K. (2012). Insurance: Organization, economics, legal aspects (p. 368). Publishing house: KURS.

Tepman, L. N., \& Eriashvili, N. D. (2011). Risk management in conditions of the financial crisis (p. 295). M.: UNITY-DANA.

Tronev, O. V. (2011). Certain methodological issues of financial stability and viability of insurance companies in crisis (p. 384). M.: Ankil.

Yuldashev, R. T., \& Tsvetkova, L. I. (2011). Insurance business development practice (p. 276). M.: Ankil.

Zhuk, I. N. (2011). Management of insurance companies competitiveness (p. 128). Publishing house: Ankil.

Note

Note $1 . \quad$ Vedomosti $\quad$ Finansy Newspaper $\quad$ [Electronic source]

URL:http://www.vedomosti.ru/finance/news/26570311/tarif-nedostatochnyj

\section{Copyrights}

Copyright for this article is retained by the author(s), with first publication rights granted to the journal. This is an open-access article distributed under the terms and conditions of the Creative Commons Attribution license (http://creativecommons.org/licenses/by/3.0/). 